\title{
Climate of the State High School Seen From Impact of Local Government Election in Mandailing Natal
}

\author{
M. Daud Batubara \\ Post Graduate Program, State University Of Padang, Indonesia
}

\begin{abstract}
This study aims to describe the portrait of school atmosphere on the country in the period before and after the direct election; Identify how teachers involvement in direct vote; identify the impact of direct election on the school atmosphere; and discussing how to overcome the direct vote impact on school atmosphere. The study was conducted by using a combination of quantitative and qualitative types of Sequential Explanatory. The study population was a civil servant (PNS) as much as 476 teachers. Research findings indicate broaden and deepen the qualitative data quantitative data with the following results: First; Images of school atmosphere before the direct vote good condition with "positive criteria" (75\%). Second; Image after the direct vote school atmosphere on the scope of government schools declined from "positive criteria" (75\%) before the direct vote, becoming "the criteria being" (51\%) after the direct vote, being in the scope of the ministry of religious schools remain on the "positive criteria" (75\%). Third; The involvement of teachers in the direct election raised secretly by bureaucratic red tape, especially by education, by way of massive, systematic and structured in two stages pre-election use persuasion and coercion election period with the approach that uses the power of pressure. Fourth; The impact on the school atmosphere on direct vote is negative, a teacher at the school rift; appear apathy, decreased morale, sense of responsibility and motivation of teachers and the achievement desire for teachers. Recommendation; Addressing the impact of direct elections to maintain a school environment can be done by: Increasing employment coaching through refinement pattern arrangement of civil procedure guidance teachers, school supervisors and principals; and empower PGRI institutions, the Board of Education and Assessment Team in order to develop the professionalism of teachers; The transfer of personnel on official coaching structural; Determination sanctions are clear, detailed and firmly against the regional head candidates violating Article 63 paragraph 1 of Regulation No 6/2005; and the determination of ethics and discipline for Head District (KDH)
\end{abstract}

Key Words: school climates, state high school, local government election.

\section{Introduction}

Bureaucracy can still be a formal government - political power (Siti, 2009:183). In concept and in practice interaction with political bureaucracy is unavoidable. For that, the government also established several laws that expressly prohibit Civil Servants (PNS) and bureaucracy to engage in practical politics, such as Law No. 43 Year 1999, prohibits civil servants as members of political party; Government Regulation No. 37 Year 2004, also establishes a ban on civil servants into a Board Member of Political Party; Government Regulation No. 6 of 2005, also published the article which prohibits Candidate Pairs involving bureaucracy. According to these Regulations, civil servants who become Members and/or Managers political parties will be dismissed as a civil servant. The provision does not prohibit political rights of civil servants, but prohibits civil servants with all the consequences to be members or officials of political parties (political practice). To that end, civil servants take a neutral stance in the process direct election of Regional Head. The process of direct election of Local Government in Madina, also allegedly has used the education sector for the success of regional head candidates. The experience of researchers who directly become a successful team in a direct election in Madina district in 2010 , teachers have been used again as a winning team in the electoral process by the bureaucracy. Experiences and observations of the principal investigators and recognition can be seen that teachers, especially those in public schools (PNS) is involved in the success of many regional head candidates. School involvement can be seen in two versions namely: (a) follow the direction of the structured bureaucracy; (b) engaged on a non bureaucratic stronghold.

Situation local government election that occurred in Madina district would bring up the pros and cons within the school that led to the formation of small groups, which are less harmonious communication, trust thinning thus ruining the atmosphere of the school. As reported by Daily Portibi Friday, 09/21/2012 p 1, which mentions that "mutations principals and teachers at the beginning of July (2012) assessed laden political interests. After three months, many school principal were become a regular teacher. Daily Tondinta, Tuesday, 25/09/2012 p 1, also revealed that 18 school principals demoted and 27 teachers moved who complain about his fate to Parliament. "They claim to the Parliament that they has three months did not teach because they did not 
know the reason for the release of mutating positions and teachers moved far from their domicile. Displacement is considered a very burdensome task of family living expenses.

Conditions of news in the media mentioned above is also in line with the initial interview with some principals and teachers that the school atmosphere in Madina district was not good enough caused by the following reasons: (a) The threat of sanctions mutation and demotion and removal of the duty positions of teachers at the time and post direct election create discomfort in the school in carrying out their duties, on the other hand must be neutral according to the rules; (b) Some principals returned into regular teacher to another school, chaotic mutation and the principal promotion and even dismissal from the post of educators perceived as a political atmosphere of educational background; (c) Some of the teachers moved to other schools after direct election of Head District, it rarely receives duty because of lack of transfer decisions to his service; (d) The occurrence of small groups of teachers among the teachers who support the incumbent, the neutral teachers and teachers who support other candidates.

School climate can thus cause teaching-learning process can not be conducted properly to the detriment of the students. It is possible to influence the quality of education in the District of Madina . In other conditions, the neutral teachers also penalized by the pair selected when holding power because it is considered as individuals who do not support. Schools in direct election of Head District process are at a pinch, whereas the teachers when viewed from the education establishment that has belonged to think as intellectuals.

\section{Literature Review}

Owens (1992:140) explains that: "school climate is a set of internal characteristics that distinguish one school with other schools and influence the behavior of people in it. School climate is the end result of a group of students, teachers, administrators who work for the balance of the organization and the individual as part of a social system". De Roche (1995: 47) argues that: "school climate include interpersonal, socio-cultural relationships that influence the behavior of individuals and groups within the school environment". Sergiovani (1997 : 97) argues that the school climate is more directed to the nature and the nature of interpersonal relationships are manifested in the attitudes and behavior of teachers, supervisors, students and principals.

From the above opinion can be seen elements of school climate are emphasized social atmosphere (likely non - physical ) because the physical environment tend to be static and easily adjusted or regulated while nonphysical more dynamic and more difficult settings; there are individuals and their interactions; is typical of a school; measured by perception; and the effect on all components. It can be concluded that the school climate is the internal atmosphere of the school is created and lived through patterns of interpersonal relationships that school personnel can be measured based on the perception of the individual that includes the principal relationship with the teachers, fellow teachers, teachers with the employee, fellow employees, teacher and students and fellow teachers with students.

Good school climate and harmonic components are needed by all schools in order to perform the role and function properly. Timpe $(1993: 21)$ explains that teachers will work more optimally if it is supported by a school climate that is good, because it can be used as motivation to produce better performance. School climate that is not conducive can lead teachers are not motivated to carry out the task properly. Siswanto (1997:71) states that a poor school climate will have a negative impact for teachers. In a school climate that is not fun, it is difficult for teachers to work quietly in carrying out their duties as appropriate lesson planning, implementing teaching-learning process and evaluate the well. Similarly, to implement classroom management guidance and do good, good school climate necessary anyway.

Direct Election of Head District as a new level of political democracy for the nation, it seems there is no relationship between the teacher with a shift political level direct local elections. However, there are many observations of education and constitutional experts who see regional autonomy system utilizing autonomous education authority as legitimate political force in direct election of Head District, through the school which leads to the formation of the pattern of coercive power by the bureaucracy to make the teacher as a political tool (HAR Tilaar 2009:89). In fact, the teacher is a profession that is highly educated community who understand their rights and responsibilities so that should not be made and not easily used as a political tool.

In modern society, the role of the teacher is very important. Therefore, we know that the status of teachers in society is very high and respected ( HARTilaar 2009:108). Teachers in simple terms is the one who gives knowledge to their students, both in formal educational institutions as well as other places such as mosques, home and other places. Syaiful $(2010: 32)$ mentions that the teachers are all people who has authority and responsibility to guide and nurture students, either individually or in a classical in school and outside of school.

Autonomous driven on school education sector so that schools and teachers have a great responsibility in improving the quality of the learning process to improve the quality of learning outcomes. Quality of student learning outcomes is the responsibility of teachers and principals, because the local government would only facilitate a variety of educational activities (Dede 2007:12). In this case the decentralized management of 
education not only in the area but the school also make management decisions and formulate their own plans in addressing the issue of education, with reference to the national education system (Fasli and Smith 2001:14). Authority to make decisions and run in accordance with the existing potential, should be up to the level of autonomy that schools have the opportunity to improve the quality of schools in the era of regional autonomy (Syafaruddin. 2008:74).

However, autonomy also gives power prone to abuse by local bureaucracy to take ruler of the kings of attitude becomes small in the area. Ismail $(2009: 11)$ revealed that the bureaucracy often did not behave as a tool of the people but has become the ruler tool and even they often manifest themselves as the rulers themselves, because co-opted into the ruling political tool in a symbiotic mutualism. When this happens, the condition of the school are vulnerable and have no bargaining power will be exploited as willing of bureaucracy.

Darmaningtyas \& Edi ( 2012: 122 ) calls, there is no doubt that the teacher is a mass political force that is promising to be able to provide political support, therefore, political campaigns have always promised to provide welfare and the like on the teacher. Sam and Tuti (2010:88) in enforcing these conditions with more extreme mention that, even education is often used as a means of strengthening the regime. With a relatively large amount, teachers and families are required by the principal of each regime to win the general election. Those who are caught not support and cast their vote on the person who directed, received the sanction would be very detrimental to himself and his family. Each arrival of the overseers hearts of all teachers and principals to vibrate faster. Added another Sam \& Emsir observations (2010 : 35) states that during this school is just an arm of the government bureaucracy to conduct political affairs education. The school administrators did not have a lot of leeway to operate autonomously school.

In a situation like this for teachers are more qualified and bold indicates an obligation to be neutral in fact not a good precedent. Darmaningtyas \& Edi (2012:123) argues that the facts obtained from the field indicates that "teachers are critical, which means to increase the quality, rather than, are loathed". Therefore, they added an explanation that, our education bureaucracy needs to be streamlined in order to provide better services effectively and efficiently, but the other side should not disadvantage the teachers are almost always the victims of discrimination" (Darmaningtyas \& Edi. 2012:140).

Teachers and families have the potential political power of the masses is relatively large with a spread of up to remote area, so it is promising to be able to provide political support. In the structure of the teachers are under bureaucracy, so that relatively more easy to approach because of the bound form of the group and their need to the bureaucracy. Hence the appeal of the teacher to the attention of the political authorities compounded because of his influence as a role model and her services to the community. Teachers become rivalry, antagonism and conflicts of interest. Be a teacher ogled to the interests of power through the education bureaucracy. Thus creating a strong relationship between political power in elections and direct election of Head District against teachers and schools by leveraging the power of the bureaucracy, this is a condition called teacher attractiveness. And the appeal of a teacher that is how they engage in approach local government election using power is the cause of school climate is not conducive.

\section{Research Methodology}

The study was conducted by using a combination of quantitative and qualitative types of Sequential Explanatory. The study population was a civil servant (PNS) as much as 476 teachers. In quantitative methods, the data collected by the questionnaire instrument uses a Likert Scale, with a sample of 192 teachers based on the formula of Isaac Michael. Qualitative methods using snowball sampling on in-depth interviews, supported by observation and study documentation. Data analysis techniques are used for descriptive statistics performed quantitative data while qualitative data is the percentage of Qualitative Data Analysis of Miles and Hubermen.

\section{Study Result}

1. Images of school climate on the land before the local elections in Mandailing Natal can be generally categorized in good condition with a value of $75 \%$ with the "positive criteria".

2. Images of school climate on the land after the local elections in Mandailing Natal generally show changes in conditions decreased from a value of $75 \%$ with "positive criteria" before direct election of Head District be the value of $51 \%$ with the "criteria of being "after direct election of Head District.

3. The involvement of teachers in the elections, acting as the winning team who deal directly with the public, raised in secret by the bureaucracy, especially the education bureaucracy, the approach is the use of power pressure.

4. Impact direct election of Head District is negative school climate in secondary schools in the country over the scope of government, which is mainly resulting negative impact on teachers, the impact of the following form:

There was a rift in the form of teachers in school groups; 
$>$ There was a sense of fear and silence against violations of rules for security purposes on the teachers themselves;

$>$ Occurs behavior learning task without any initiative to better, which it is performed simply abdicate responsibility

$>$ Appears apathetic attitude towards the possibility of the system will change for the better;

$>$ Decreased morale and motivation of teachers that affect achievement pullback desire for teachers.

$>$ Degradation of the credibility of the professionalism of teachers in society; affect its identity, a sense of pride and spirit teachers decreased.

$>$ The occurrence of a habit of breaking the rules by the teacher, as a prolonged moral burden for teachers;

$>$ The suppression of the teacher in carrying out the task due to the strong pressure of bureaucratic power for political purposes direct election of Head District (KDH).

$>$ Damage to the structure formation process and career development of employees/ teachers as a result of the dominance of abuse of authority and power by the bureaucracy of the teacher.

$>$ Physically going development with political orientation is a light house that do not comply with requirements and standards of facilities and infrastructure that affect the learning process and the quality of graduates.

\section{Recommendation;}

Addressing the impact of direct elections to maintain a school environment can be done by: Increasing employment coaching through refinement pattern arrangement of civil procedure guidance teachers, school supervisors and principals; and empower PGRI institutions, the Board of Education and Assessment Team in order to develop the professionalism of teachers; The transfer of personnel on official coaching structural; Determination sanctions are clear, detailed and firmly against the regional head candidates violating Article 63 paragraph 1 of Regulation No 6/2005; and the determination of ethics and discipline for Head District.

\section{References}

[1]. Darmaningtyas \& Edi Subkhan. 2012 Manipulasi Kebijakan Pendidikan. Resist Book. Jakarta

[2]. De Roche, E.F. 1995. How School Administrators Solve Problem. New Jersey: Prentice Hill.

[3]. Dede Rosyada 2007 Paradigma Pendidikan Demokratis Sebuah Model Pelibatan Masyarakat dalam Penyelenggaraan Pendidikan. Jakarta: Kencana

[4]. Fasli Jalal \& Dedi Suoriadi 2009. Reformasi Pendidikan Dalam Konteks Otonomi Daerah. Yokyakarta: Adicita Karya Nusa.

[5]. Ismail 2009. Politisasi Birokrasi. Malang: Averreos Prees

[6]. Kartini Kartono 2012. Pemimpin dan Kepemimpinan, Apakah Pemimpin Abnormal Itu. Jakarta. Rajawali Pers.

[7]. Miles, Matthew B \& Huberman A. Michael. 1994. Data Management and Analysis Methods. Thousand Oaks, CA: Sage. p $428-429$.

[8]. Sam M. Chan \& Emsir (Ed). 2010. Isu-Isu Kritis Kebijakan Pendidikan Era Otonomi Daerah. Bogor. Ghalia Indonesia.

[9]. Siti Zuhro. R 2009 Demokrasi Lokal, Peran Aktor Dalam Demokratisasi, Yokyakarta: Ombak

[10]. Syafaruddin. 2008. Efektifitas Kebijakan Pendidikan, Konsep, Strategi, dan Aplikasi Kebijakan Menuju Organisasi Sekolah Efektif. Rineka Cipta. Jakarta

[11]. Siswanto. 2010. Organisasi Sekolah Masa Depan, Jakarta. Prenhallindo

[12]. Tilaar. H.A.R. 2002. Membenahi Pendidikan Nasional. Jakarta. Rineka Cipta

[13]. Undang-Undang Nomor 43 Tahun 1999 Perubahan Undang-Undang Nomor 08 Tahun 1974 tentang Pokok-Pokok Kepegawaian

[14]. Undang-Undang Republik Indonesia Nomor 32 Tahun 2004 Tentang Pemerintahan Daerah. Jakarta: Eko Jaya

[15]. Undang-Undang Republik Indonesia Nomor 20 Tahun 2003 Tentang Sistem Pendidikan Nasional, Jakarta: Sekneg 2005.

[16]. Undang-Undang Nomor 5 tahun 2014 tentang Aparatur Sipil Negara, Jakarta,CV. Eko Jaya. 2014.

[17]. Peraturan Pemerintah Republik Indonesia Nomor 6 Tahun 2005 Tentang Pemilihan Pengesahan Pengangkatan dan Pemberhentian Kepala Daerah, Jakarta: Departemen Dalam Negeri Republik Indonesia.

[18]. Harian Portibi Jumat 21/09/2012,. Mutasi Kepsek Sarat Kepentingan Politik. Hlm. 1

[19]. Harian Tondinta, Selasa 25/09/2012 hlm 1, Guru Adukan Nasib ke DPRD. Hlm. 1 